\title{
Temperament, Character Traits and Alexithymia in Patients with Asthma; A University Hospital Sample*
} Astım Hastalarında Mizaç, Karakter Özellikleri ve Aleksitimi; Bir Üniversite Hastanesi Örneği Eda Aslani, Fatih Sağlamii, Sibel Nayciii

'Asst.Prof., Mersin University, Faculty of Medicine, Department of Psychiatry, https://orcid.org/0000-0002-8795-2834 iiMD., Siirt State Hospital, https://orcid.org/0000-0001-7478-8521

iiiProf., Mersin University, Faculty of Medicine, Department of Pulmonary Diseases, https://orcid.org/0000-0002-8415-5717

\begin{abstract}
Background: The relationship between psychological factors and asthma has received attention since very early times. However, there's a lack of knowledge about the temperament and character features of asthma patients. We aimed to assess if there are specific personality traits in asthma patients.
\end{abstract}

Methods: Thirty-eight patients with asthma and thirty-five healthy individuals were enrolled in the study. The sociodemographic data form and Temperament and Character Inventory (TCI) and Toronto Alexithymia Scale (TAS) were applied to all participants.

Results: The mean age was $40.9 \pm 15.9$ in the asthma group $(52.1 \%)$ and $37.3 \pm 14.3$ in the control group (47.9\%). There were 29 females and 9 males in asthma group, 19 females and 16 males in control group. In analysis of temperament and character subscales, the scores of harm avoidance, frugality, sentimentality and transpersonal identification were higher in asthma patients than the control group; the differences were statistically significant $(p<0.05)$. There were no significant differences between the groups for alexithymia $(p>0.05)$

Conclusions: Our study showed that there were character and temperament differences between asthma patients and healthy group. There were no differences for alexithymia between the groups. Further studies are needed to evaluate the causes of differences and the impacts of traits on disease course.

Key Words: Asthma, Personality, Temperament, Character

Öz

Amaç: Astım ve psikolojik faktörler arasındaki ilişki çok eski zamanlardan bu yana ilgi çeken bir konudur. Bununla ilgili birçok araştırma yapılmasına rağmen halihazırda astım hastalarının mizaç ve karakter özellikleri hakkında literatür bilgisi sınırlıdır. Biz çalışmamızda astım hastalarında mizaç, karakter ve aleksitimik özellikleri araştırmayı amaçladık.

Yöntem: Çalışmaya astım tanısı alan 38 hasta ve 35 sağlıklı gönüllü katılmıştır, tüm katılımcılara sosyodemografik veri formu, "Mizaç ve Karakter Envanteri “(MKE) ve "Toronto Aleksitimi Ölçeği” (TAÖ) uygulanmıştır.

Bulgular: Çalışmamızda Astım tanısı alan 38 kişinin yaş ortalaması $40.9 \pm 15.9$, sağıklı gönüllülerin yaş ortalaması $37.3 \pm 14.3$ olarak bulunmuştur. Astım grubu 29 kadın, 9 erkek, sağlıklı grup 19 kadın, 16 erkekten oluşmuştur. Astım hastalarında MKE'ye göre "zarardan kaçınma", "tutumluluk", "duygusal hassasiyet" ve "kişilerarası özdeşleşme" puanları kontrol grubuna göre daha yüksektir, farklılık istatistiksel olarak anlamlı bulunmuştur $(\mathrm{p}<0.05)$. Aleksitimi açısından gruplar arasında anlamlı farklılık saptanmamıştır $(p>$ 0.05).

Sonuç: Çalışmamız astım hastaları ile sağlıklı gönüllüler arasında karakter ve mizaç özellikleri bakımından farklıııklar olduğunu, aleksitimi düzeyleri açısından ise fark olmadığını göstermiştir. Bu farklıııların nedenleri ve bu özelliklerin hastalık seyri üzerindeki etkilerini değerlendirebilmek için daha fazla çalışmaya ihtiyaç vardır.

Anahtar Kelimeler: Astım, Kişilik, Mizaç, Karakter

\footnotetext{
${ }^{*}$ Mersin Üniversitesi Tıp Fakültesi Lokman Hekim Tıp Tarihi ve Folklorik Tıp Dergisi, 2022; 12 (1): 86-94

DOI: $10.31020 /$ mutftd.927090

e-ISSN: 1309-8004, ISSN 1309-761X

Geliş Tarihi - Received: 24 April 2021; Kabul Tarihi - Accepted: 27 October 2021

iletişim - Correspondence Author: Eda Aslan <dredaaslan@yahoo.com>

Ethical Approval: Ethics committee of Mersin University (Reference Number: 78017789/050.01.04/11-2015/88)
} 


\section{Introduction}

Asthma is a chronic condition affecting both children and adults, the aetiology of which is still not clear. It is defined as a multifactorial disease associated with allergic, genetic, environmental, emotional, and nutritional components, but the exact cause of asthma remains unclarified.

\section{History of Asthma}

When we look at the history of asthma, we see a long story of evolution before it was categorically defined. The earliest mention of respiratory distress and wheezing has been found in 2600 BC in China. "Code of Hammurabi" (proclaimed by the Babylonian king Hammurabi) recorded symptoms of being breathless in 1792 BC. An Egyptian medical papyrus of herbal knowledge dating to 1550 BC suggested a mixture of herbs to inhale their fumes as treatment for asthma. The term asthma is derived from a Greek word "aazein" that means "exhaling with open mouth". In Iliad by Homer, "asthma" term used for shortening of breath but for the first usage as a medical word is found in the Corpus Hippocraticum (460-360 BC). Hippocrates mentioned the environmental triggers in the occurrence of asthma. In 129 AD, Claudius Galen, suggested that breathing was a function of muscular contraction and he is credited as being the first to describe asthma as a disease of constriction of the airways in the lungs. Aztecs (1300-1500) are known to use ephedra containing plants and Incas (1500) treated asthma with cocaine-like dried leaf for mucus clearance. ${ }^{1}$

In the 1800s Canadian scientist, Sir William Osler, defined asthma as inflammation and bronchospasm in "The Principles and Practice of Medicine". He stated that asthma attacks occur with nervous stimulation. His research led to the idea that asthma was a psychosomatic disease and led research about psychosomatic diseases. $^{2}$

\section{Psychosomatic Explanations}

In 1930 and 40s, the psychosomatic explanations were popular and psychoanalytic principles were applied to physical illnesses. Alexander and French were lead founders of the psychosomatic movement, they explained that if patient cannot find the express their emotions by word or action, the body will find a way to express this tension; and they called "organ language" to this situation. ${ }^{3}$ The first president of the American Psychosomatic Society (APS); Helen Flanders Dunbar's idea was personality type as a predisposing factor in asthma and in other psychosomatic diseases. ${ }^{4}$ APS suggested that asthma attacks occurred as the result of longing for attention of the mother. An asthmatic attack was interpreted as a suppressed cry for the mother's help. Patients with asthma were described on a smothering relationship with a mother figure. An intervention called "parentectomy" were suggested by Dr. Murray Peshkin who was the medical director of "Center for Immunology and Respiratory Medicine", noticed that hospitalized children recovered before any treatment. Peshkin thought that improvement was the result of separating children from environment (emotional factors and allergic agent). ${ }^{5}$ But the findings of studies about parentectomy did not support the idea and the intervention was disclaimed by the other researchers from the same institute. ${ }^{6}$ Psychosomatic explanations of asthma remained popular in the $X X^{\text {th }}$ century until biomedical understanding was increased. As the explanations and understanding of allergens and chemical mediators in 1980s, biologic treatment options increased. 


\section{The Sum of Temperament and Character; Personality}

\section{Historical Perspective}

Temperament referred to dimensions of personality that are inherited and innate, not learned and character is shaped by effect of environmental factors. Personality is a sum of person's stable behavioural patterns determined by genetics and environment. ${ }^{7,8}$

The word "personality" comes from the Latin word "persona". In Ancient Greek, a persona was a mask worn by actors which was used to project a specific personality. The history of personality dates to the Ancient Greece. ${ }^{9}$ Since the IVth Century BC, philosophers have been trying to define human behaviour. In $370 \mathrm{BC}$, Hippocrates suggested two substructures of temperament: hot-cold and moist-dry combinations. Yellow bile causes hot and dry temperament (choleric), black bile causes cold and dry temperament (melancholic), red blood refers hot and wet temperament (sanguine) and white phlegm refers cold and wet temperament (phlegmatic). ${ }^{10}$ Galen developed Hippocrates's theory, suggesting diseases and personalities could be explained by imbalances of fluids of body which caused one of the four temperaments. The choleric temperament is ambitious and passionate; the melancholic temperament is anxious and unhappy; the sanguine temperament is optimistic, joyful; and the phlegmatic temperament is thoughtful and calm. ${ }^{11}$ Galen's theory was popular through the Middle Ages. Philosophical and anthropological thinking also played an important role in the explanation of personality. Scholars like Immanuel Kant, Friedrich Wilhelm Nietzsche, Emil Kraepelin, Alfred Adler developed theories of human behaviour functioning but evidence was limited.

\section{Empirical Analyses in Modern Era}

Hans Eysenck, Robert Cloninger and Hagop Akiskal developed empirical theories of temperament and character traits and dimensions. The first researcher who analysed personality traits in an empirical method was Hans Eysenck. ${ }^{8}$ He suggested the basic traits; neuroticism (tendency to negative emotions), extraversion (tendency to positive emotions) and psychoticism (cognitive changes). Currently the theories of temperament and character are represented by two major questionnaires, the TCI and the TEMPS-A. ${ }^{12}$ Robert Cloninger's psychobiological model of personality is a dimensional approach. Temperament and Character Inventory (TCl) measures both normal and abnormal personality traits in temperament and character dimensions. ${ }^{7}$ It suggests the existence of four dimensions of temperament; harm avoidance, reward dependence and novelty seeking that appear in early life and are considered as heritable and persistent, and three dimensions of character that mature in adulthood influenced by environmental factors such as social and cultural learning. Cloninger showed that behavioural variation is the result of genetic and environmental influences.

Alexithymia was first described by Sifneos in 1972 as the result of deterioration in affective and cognitive functions causing an inability to recognize and identify feelings and express emotions verbally. In this concept, it is stated that there are problems in distinguishing emotional symptoms from somatic symptoms and expressing feelings with physical signs; it has been suggested that alexithymia is a characteristic core symptom in patients with psychosomatic diseases. ${ }^{13,14}$

Previous research has suggested different personality types in asthma, such as emotional sensitivity, anxiety, neuroticism but research with Cloninger's psychobiological model of personality in asthma is limited. ${ }^{15,16}$

Furthermore, constant anxiety caused by the uncertainty of the attacks from a very young age and parents' overbearing the child due to chronicle pattern of the disease and restrictive aspects of life from very early ages would have potential effect on character structure. Chronic hypoxemia can also cause disturbances in the brain neurotransmitter synthesis, which has been said to lead to a variety of behaviour patterns and 
psychiatric symptoms. ${ }^{17}$ Therefore, the aim of the present study was to identify psychobiological model of personality and alexithymia in asthma patients.

\section{Methods}

The study included patients diagnosed with asthma according to the GINA (Global Initiative for Asthma) criteria $^{18}$. The scales were administered by one psychiatrist and one asthma nurse in Pulmonary Diseases Outpatient Clinic of Mersin University, Medical Faculty, on a day of the week determined by the department and the study was conducted between February 2016 and March 2018. Participants with major psychopathology according to a semi-structured psychiatric interview and those previously diagnosed with another medical disease were excluded from the study. 60 patients and 60 healthy volunteers were asked to participate in the study. 22 of the asthma patients and 12 of the healthy volunteers we interviewed were excluded from the study due to having additional medical and/or mental illnesses. The number of participants who did not want to continue with the survey during the interviews was 13 from healthy group. A total of 47 people was excluded from the study. The study was completed with 38 patients and 35 healthy individual.

The sociodemographic characteristics such as gender, marital status, educational status, place of residence, age at onset of the disease, and duration of illness were recorded for all patients. The Temperament and Character Inventory (TCI) and the Toronto Alexithymia Scale (TAS) were applied. Written informed consent was obtained from each participant.

Approval for the study was granted by the Ethics committee of Mersin University with the number; 78017789/050.01.04/11-2015/88.

Toronto Alexithymia Scale (TAS): This self-evaluation scale was developed by Bagby et al to evaluate the level of alexithymia. The scale has 20 items, the Likert-type responses for all items are scored from 1-5. In the current study, the cut-off value of the scale was accepted as 60, and thus scores of 60 and above were accepted as indicating alexithymia. The Turkish validity and reliability study was conducted by Gulec et al. ${ }^{19}$

Temperament and Character Inventory ( $\mathrm{TCl})$ : The inventory was developed based on Cloninger's personality theory and is a self-assessment scale of 240 items. ${ }^{20}$ The Turkish validity and reliability study was performed by Köse et al. ${ }^{21}$

Statistical analysis: The conformity of continuous variables to normal distribution was tested with the Shapiro Wilk test. Differences between the patient and control groups in terms of character and temperament scale scores were evaluated with the Independent Samples t-test. Descriptive statistics were stated as number $(n)$ and percentage (\%). A value of $p<0.05$ was accepted as statistically significant.

\section{Results}

The study group consisted of 38 (52.1\%) patients with a mean age of $40.9 \pm 15.9$, and a control group of 35 $(47.9 \%)$ healthy individuals with a mean age of $37.3 \pm 14.3$. There was no statistically significant difference between the groups in terms of the mean age $(p=0.320)$. The mean age was found to be $38.5 \pm 15.1$ in females and $40.5 \pm 15.3$ in males with no statistically significant difference determined between the genders $(p=$ $0.592)$.

The descriptive statistics (number and percentage) of the participants are shown in Table 1. A significant difference was determined between the groups in terms of gender, educational status and place of residence $(p=0.048 ; p=0.015$ and $p=0.006$ ). The descriptive statistics (number and percentage) and $p$ values of these parameters are given in Table 1. 
Table 1. Differences of Sociodemographic Data Between Asthma Patients and Healthy-Control Group.

\begin{tabular}{|c|c|c|c|c|c|c|}
\hline & & \multicolumn{2}{|c|}{ Patient } & \multicolumn{2}{|c|}{ Control } & \multirow[t]{2}{*}{ p-value } \\
\hline & & $\mathbf{N}$ & $\%$ & $\mathbf{N}$ & $\%$ & \\
\hline \multirow[t]{2}{*}{ Gender } & Female & 29 & 76.3 & 19 & 54.3 & $0.048^{* *}$ \\
\hline & Male & 9 & 23.7 & 16 & 45.7 & \\
\hline \multirow[t]{2}{*}{ Marital Status } & Single & 18 & 47.4 & 20 & 57.1 & 0.404 \\
\hline & Married & 20 & 52.6 & 15 & 42.9 & \\
\hline \multirow[t]{3}{*}{ Education } & Low & 10 & 26.3 & 5 & 14.3 & $0.015^{* *}$ \\
\hline & Low-middle & 11 & 28.9 & 3 & 8.6 & \\
\hline & High & 17 & 44.7 & 27 & 77.1 & \\
\hline \multirow[t]{2}{*}{ Employment } & Employed & 32 & 84.2 & 24 & 68.6 & 0.114 \\
\hline & Unemployed & 6 & 15.8 & 11 & 31.4 & \\
\hline \multirow[t]{2}{*}{ Residence } & Urban & 23 & 60.5 & 31 & 88.6 & $0.006 * *$ \\
\hline & Rural & 15 & 39.5 & 4 & 11.4 & \\
\hline
\end{tabular}

${ }^{*} \mathrm{~N}$ : number ${ }^{* *} A$ value of $\mathrm{p}<0.05$ was accepted as statistically significant

The differences between the groups in terms of character and temperament sub-dimension scales were examined and the descriptive statistics (mean and standard deviation) and $p$ values are given in Tables $\mathbf{2}$ and 3. HA2, HA4, HA total, RD1, and ST2 scores were statistically significantly higher in patients than in the control group and the NS3 scores were determined to be significantly higher in the control group ( $p$ values; 0.033; $0.023 ; 0.029 ; 0.036,0.011,0.05$ respectively). According to the Toronto Alexithymia Scale, alexithymia was found in 4 patients and 6 control subjects. There was no statistical difference between the two groups in terms of the TAS total score (Table 4).

Table 2. Comparison of Temperament Dimensions' Scores Between Asthma Patients and Healthy-Control Group

\begin{tabular}{llll}
\hline $\begin{array}{l}\text { TCl; Temperament Dimensions } \\
\text { Sub-scales }\end{array}$ & $\begin{array}{l}\text { Patient }(\mathbf{n}=\mathbf{3 8}) \\
\text { Mean } \pm \text { SD }\end{array}$ & $\begin{array}{l}\text { Control }(\mathbf{n}=\mathbf{3 5}) \\
\text { Mean } \pm \text { SD }\end{array}$ & p-value* \\
\hline Novelty Seeking (NS) & & & \\
NS1 (exploratory excitability) & $5.3 \pm 2.2$ & $5.6 \pm 1.5$ & 0.410 \\
NS2 (impulsiveness) & $3.6 \pm 1.9$ & $3.9 \pm 1.7$ & 0.590 \\
NS3 (extravagance) & $4.0 \pm 1.9$ & $4.9 \pm 1.8$ & 0.050 \\
NS4 (disorderliness) & $3.9 \pm 1.4$ & $4.1 \pm 1.9$ & 0.781 \\
NS Total & $16.9 \pm 4.2$ & $18.4 \pm 4.7$ & 0.136 \\
Harm Avoidance (HA) & & & \\
HA1 (anticipatory worry) & $5.84 \pm 2.22$ & $5.37 \pm 2.24$ & 0.371 \\
HA2 (fear of uncertainty) & $4.68 \pm 1.61$ & $3.83 \pm 1.76$ & 0.033 \\
HA3 (shyness) & $3.74 \pm 2.00$ & $2.91 \pm 2.27$ & 0.105 \\
HA4 (fatigability) & $5.21 \pm 2.12$ & $3.97 \pm 2.44$ & 0.023 \\
HA Total & $19.47 \pm 6.18$ & $16.09 \pm 6.81$ & 0.029 \\
Reward Dependence (RD) & & & \\
RD1 (sentimentality) & $7.39 \pm 1.50$ & $6.54 \pm 1.90$ & 0.036 \\
RD3 (social attachment) & $3.71 \pm 1.64$ & $4.11 \pm 1.64$ & 0.297 \\
RD4 (dependency) & $2.18 \pm 1.27$ & $2.51 \pm 1.52$ & 0.316 \\
RD Total & $13.37 \pm 2.76$ & $13.20 \pm 3.24$ & 0.812 \\
Persistence & $5.03 \pm 1.99$ & $5.46 \pm 2.02$ & 0.362 \\
\hline
\end{tabular}

TCl: Temperament and Character Inventor, n: number, SD: Standard Deviation, ${ }^{*} \mathrm{~A}$ value of $\mathrm{p}<0.05$ was accepted as statistically significant 
Table 3. Comparison of Character Dimensions' Scores Between Asthma Patients and Healthy-Control Group

\begin{tabular}{llll}
\hline $\begin{array}{l}\text { TCl; Character Dimensions } \\
\text { Sub-scales }\end{array}$ & $\begin{array}{l}\text { Patient }(\mathbf{n}=\mathbf{3 8}) \\
\text { Mean } \pm \text { SD }\end{array}$ & $\begin{array}{l}\text { Control }(\mathbf{n}=\mathbf{3 5}) \\
\text { Mean } \pm \text { SD }\end{array}$ & p-value* \\
\hline Self-Directedness (SD) & & & \\
SD1 (Responsibility) & $4.79 \pm 2.12$ & $5.14 \pm 2.22$ & 0.489 \\
SD3 (Resourcefulness) & $3.26 \pm 1.31$ & $3.06 \pm 1.19$ & 0.485 \\
SD4 (Self-acceptance) & $4.68 \pm 2.27$ & $5.11 \pm 2.63$ & 0.456 \\
SD5 (Enlightened second nature) & $8.11 \pm 2.44$ & $8.54 \pm 1.82$ & 0.391 \\
SD Total & $26.61 \pm 6.53$ & $27.51 \pm 3.96$ & 0.550 \\
Collaboration (C) & & & \\
C1 (Social acceptance) & $6.13 \pm 1.61$ & $6.14 \pm 1.68$ & 0.977 \\
C2 (Empathy) & $4.55 \pm 1.31$ & $4.66 \pm 1.43$ & 0.746 \\
C3(Helpfulness) & $4.68 \pm 1.38$ & $4.57 \pm 1.14$ & 0.706 \\
C4 (Compassion) & $7.89 \pm 1.78$ & $7.40 \pm 2.51$ & 0.339 \\
C5 (Principled) & $6.92 \pm 1.53$ & $6.43 \pm 1.48$ & 0.168 \\
C Total & $30.18 \pm 4.89$ & $29.20 \pm 5.33$ & 0.414 \\
Self-Transcendence (ST) & & & \\
ST1 (Self-forgetful) & $6.37 \pm 2.34$ & $5.94 \pm 2.63$ & 0.467 \\
ST2 (Transpersonal identification) & $5.71 \pm 1.96$ & $4.46 \pm 2.16$ & 0.011 \\
ST3 (Spiritual acceptance) & $7.08 \pm 2.62$ & $7.26 \pm 3.00$ & 0.788 \\
ST Total & $19.16 \pm 5.21$ & $17.66 \pm 5.64$ & 0.241 \\
\hline
\end{tabular}

TCl: Temperament and Character Inventor, n: number, SD: Standard Deviation, ${ }^{*}$ A value of $p<0.05$ was accepted as statistically significant

Table 4. Comparison of Toronto Alexithymia Scales' Scores Between Asthma Patients and Healthy-Control Group

\begin{tabular}{llll}
\hline $\begin{array}{l}\text { Toronto Alexithymia Scale (TAS) } \\
\text { Sub-scales }\end{array}$ & $\begin{array}{l}\text { Patient }(\mathbf{n}=\mathbf{3 8}) \\
\text { Mean } \pm \text { SD }\end{array}$ & $\begin{array}{l}\text { Control }(\mathbf{n}=\mathbf{3 5}) \\
\text { Mean } \pm \text { SD }\end{array}$ & p-value* \\
\hline TAS1 (Difficulty identifying feelings) & $16.05 \pm 4.50$ & $13.91 \pm 4.82$ & 0.054 \\
TAS2 (Difficulty describing feelings) & $12.39 \pm 3.46$ & $11.46 \pm 3.61$ & 0.261 \\
TAS3 (Externally-oriented thinking) & $21.16 \pm 4.65$ & $22.43 \pm 5.46$ & 0.287 \\
TAS Total & $49.61 \pm 10.54$ & $48.06 \pm 10.97$ & 0.541 \\
\hline
\end{tabular}

TCl: Temperament and Character Inventor, n: number, SD: Standard Deviation, ${ }^{*} A$ value of $p<0.05$ was accepted as statistically significant

\section{Discussion}

The results of this study showed that the total score of "harm avoidance" was significantly higher in the patient group than in the control group. The "fear of uncertainty" and "fatigability" subscale scores of HA were higher in the patient group. The RD subscale "sentimentality" score was higher and the NS subscale "extravagance" score was lower in patients. The self-transcendence subscale "transpersonal identification" score was higher in patients, and all those differences were statistically significant whereas differences between the groups were not significant for alexithymia.

Individuals with high scores in HA are defined as cautious, attentive, fearful, anxious, shy, skeptical, passive and pessimistic, with low courage and self-confidence. These people are restrained in their social environment, are shy, have low energy levels, tire easily, and are sensitive to criticism. People with low HA scores tend to be relaxed, sociable, carefree, courageous and optimistic. ${ }^{20,22}$ Although no particular temperament and character profile has been defined as more predominant in patients with psychosomatic diseases, it has been reported that some personality traits such as harm avoidance are more common in people with chronic diseases. In previous studies, HA scores are higher in patients with psychosomatic diseases such as atopic dermatitis, tension-type headache, and fibromyalgia. ${ }^{23,24,25}$ Medine et al. showed that HA was high in asthma patients. ${ }^{26}$ Under these findings in literature, the HA scores were higher in the patient group of the current study compared to the control group. People with "fear of uncertainty" avoid taking risks and deteriorating the routine, which is a symptom that can lead to various mental disorders, especially anxiety. Asthma is a disease that occurs with attacks, usually from a young age. A long-term 
continuous fear of experiencing shortness of breath can both affect personality traits and may cause various psychiatric problems, especially anxiety disorders. Besides, continuous family dependence, frequent hospitalization, limitation of activities, and prolonged stress may also hinder the development of coping strategies by the patient. A high "fatigue" score may be related to the burnout feeling due to the chronic nature of the disease. A recent research which studied personality characteristics of elderly subjects and young subjects with asthma showed that elderly patients had higher level of avoidance-oriented coping, distraction seeking and social diversion compared to young asthmatics. That finding can be interpreted as asthma may have a continuous structural effect on character development.

A low score on the extravagance subscale indicates restraint in self-control, in money, and energy expenditure; these people prefer to live within certain limits. The low extravagance subscale score in asthma patients may be caused by an intolerance to uncertainty and the fact that various life events may trigger asthma, hence they avoid things that disrupt their routine.

Those who score higher in the "sentimentality" subscale is sensitive to rejection, and have high emotion expression and can empathize with people around and therefore tend to be social and friendly, whereas those who score lower do not give importance to the feelings of others, and are emotionally cold and distant. In the current study, the sentimentality scores of the asthma patients were significantly higher than those of the control group. French and Alexander hypothesized that an unconscious conflict of dependency issues with the mother and fear of separation causes asthma attacks and asthma represents a suppressed cry. ${ }^{3}$ The Chicago Institute for Psychoanalysis also stated a psychodynamic conflict, with asthma patients showing repressed dependence on the mother, patient wants to be accepted and protected by the mother and fears separation, thus aggressive or hypersensitive behaviour may occur. ${ }^{27}$

People who score higher in the "transpersonal identification" scale see themselves as a part of the universe, are altruistic, and tend to help other people. They think that every individual is a part of the whole and that people should make sacrifices to make the world a better place. Those who score lower on this scale have no special ties to nature and people, do not like to sacrifice and tend to be individualistic. In the current study, the transpersonal identification score was higher in asthma patients. Some studies have shown that seeing each person as part of the whole universe rather than as isolated individuals is thought to make life more successful and feel better in many ways. ${ }^{28}$ In a study of cancer patients, transpersonal attachments were found to be associated with disease-related anxiety, quality of life and the state of well-being. ${ }^{29}$ Transpersonal identification may be defined as a personality trait, which causes positive outcomes especially in the fight against chronic diseases.

Alexithymia is considered as a personality trait that results in susceptibility to psychosomatic diseases. ${ }^{14}$ Although it is seen in somatic, psychosomatic and mental disorders, alexithymia does not improve even if the disease recovers and this finding has led to the acceptance of alexithymia as a personality trait. ${ }^{30}$ It has been reported that people with alexithymia do not recognize emotional stimulation and often use physical symptoms to express their feelings. ${ }^{13}$ Although alexithymia has been reported to be seen in healthy populations in recent studies, its role in somatization is still a matter of debate. ${ }^{31}$ In many studies, alexithymia levels are high in asthma, which is a known risk factor for the poor quality of life and poor disease control. ${ }^{32-}$ 34

Contrary to expectations, the alexithymia levels in the asthma patients of the current study were similar to those of the control group, with no statistically significant differences between the groups.

There are several limitations in our study, primarily the cross-sectional design and small sample size. One clinician could be able to administer the questionnaire on a specific day of the week in the Pulmonary 
Diseases Outpatient Clinic. TCl includes approximately 240 items and takes more than one hour to complete. Patients were reluctant to participate in the study due to long interview period. All those factors unfortunately caused our sample to be smaller. We did not evaluate the presence of a current attack, the severity of attacks, control of the disease and medication used which may be considered as limitations. However, we must emphasize that the main goal of the study was to focus on personality traits seen in asthma patients. There is surely a need for further studies with larger samples and longer follow-up periods to determine the effects of personality traits on the characteristics of asthma and treatment compliance and conversely the effects of the characteristics of asthma and medication on personality traits.

In conclusion, the results of this study showed that harm avoidance, frugality, sentimentality, and transpersonal identification personality traits are common in asthma patients. Children and adults across the world live in fear and isolation due to their asthma. Separation from their school, workplace and public areas in constant fear affects individual's psychology. More can be done to improve the lives of people with asthma and prevent the burden but first we have to learn their psychological needs without blaming them for neither negative emotions and behaviors nor exacerbations of asthma attacks.

\section{Acknowledgement}

No sources of financial support. No conflict of interest

Ethical approval: Approval for the study was granted by the Ethics committee of Mersin University with the number; 78017789/050.01.04/11-2015/88.

\section{Author contributions}

Eda Aslan: Literature search, data collection, study design, analysis of data, manuscript preparation, review of manuscript.

Fatih Sağlam: Data collection, study design, analysis of data, manuscript preparation. Sibel Naycl: Data collection, study design, analysis of data, manuscript preparation.

\section{References}

1. Baas JH. Outlines of the history of medicine and the medical profession. In: Anderson HE, editor. New York: JH Hill\&Co; 1889. pp: 881-913

2. Osler W. Diseases of the respiratory system: bronchial asthma. In: The principles and practice of medicine, 4th ed. New York: D. Appleton and Company; 1901. pp: 628-632

3. Alexander F, French TM. Psychoanalytic therapy. New York: Ronald Press. 1946. pp. 353

4. Dunbar HF. Psychoanalytic Notes Relating to Syndromes of Asthma and Hay Fever. The Psychoanalytic Quarterly 2017;7(1):25-68. doi:10.1080/21674086.1938.11925341

5. Peshkin MM. Asthma in children: i. Etiology. Am J Dis Child 1926;31(6):763-814. doi:10.1001/archpedi.1926.04130060002001

6. Purcell K, Bernstein L, Bukantz SC. A preliminary comparison of rapidly remitting and persistently "steroid-dependent" asthmatic children. Psychosomatic Medicine 1961;23.4: 305-310.

7. Cloninger CR, Svrakic DM, Przybeck TR. A psychobiological model of temperament and character. Arch Gen Psychiatry 1994;50: 975-990.

8. Eaves L, Eysenck H. Genetic and environmental components of inconsistency and unrepeatability in twins' responses to a neuroticism questionnaire. Behav Genet 1976 62. 1976;6(2):145-160. doi:10.1007/BF01067145

9. Clay D. The Theory of the Literary Persona in Antiquity. Mater e Discuss per I'analisi dei testi Class 1998;(40):9. doi: $10.2307 / 40236116$

10. Widiger T A, Smith GT. Personality and psychopathology. In O. P. John, R. W. Robins, \& L. A. Pervin (Eds.),. Handb Personal Theory Res, 2008; The Guilfo:743-769.

11. Watson D, Clark LA, Chmielewski M. Structures of Personality and Their Relevance to Psychopathology: II. Further Articulation of a Comprehensive Unified Trait Structure. J Pers 2008;76(6):1545-1586. doi:10.1111/J.1467-6494.2008.00531.X

12. Akiskal HS, et al. TEMPS-A: validation of a short version of a self-rated instrument designed to measure variations in temperament. J Affect Disord 2005;85(1-2):45-52. doi:10.1016/J.JAD.2003.10.012

13. Sifneos PE. Alexithymia: Past and present. Am J Psychiatry 1996;153(7):137-142. doi:10.1176/ajp.153.7.137 
14. Apfel RJ, Sifneos PE. Alexithymia: Concept and measurement. Psychother Psychosom 1979;32(1-4):180-190. doi:10.1159/000287386

15. Belloch A, et al. Bronchial asthma and personality dimensions: a multifaceted association. J Asthma 1994;31:161-170, doi: 10.3109/02770909409044822.

16. Huovinen E, Kaprio J, Koskenvuo M. Asthma in relation to personality traits, life satisfaction, and stress: a prospective study among 11,000 adults. Allergy 2001;56(10):971-7. doi: 10.1034/j.1398-9995.2001.00112.x.

17. Kumar GK. Hypoxia and neurotransmitter synthesis. Am J Physiol Cell Physiol 2011;300(4):C743-51. doi:10.1152/ajpcell.00019.2011

18. Global Initiative for Asthma. GINA Report: Global Strategy for Asthma Management and Prevention 2017. doi:10.1002/uog.8947

19. Güleç $\mathrm{H}$, et al. Reliability and factorial validity of the Turkish version of the 20-item Toronto alexithymia scale (TAS-20). Klin Psikofarmakol Bul 2009;19(3):215-221. doi:10.1016/S0022-3999(03)00360-X

20. Cloninger CR. A systematic method for clinical description and classification of personality variants. A proposal. Arch Gen Psychiatry 1987;44: 573-588

21. Köse S, et al. Mizaç ve Karakter Envanteri (Türkçe TCI): Geçerlik, güvenirliǧi ve faktör yapisi. Klin Psikofarmakol Bul. 2004;14(3):107131.

22. Cloninger CR, et al. A Psychobiological Model of Temperament and Character. Arch Gen Psychiatry 1993;50(12):975-990. doi:10.1001/archpsyc.1993.01820240059008

23. Kim T-, et al. Temperament and character dimensions in patients with atopic dermatitis. J Dermatol 2006;33(1):10-15. doi:10.1111/j.1346-8138.2006.00002.x

24. Boz C, et al. Kronik Gerilim Tipi Baş Agrili Hastalarda Mizaç ve Karakter Profili. Turk Psikiyatri Derg 2004;15(2):105-111.

25. Altunören $\mathrm{O}$, et al. Evaluation of depression, temperament and character profiles in female patients with fibromyalgia syndrome. Noropsikiyatri Ars 2011;48(1):31-38. doi:10.4274/npa.y5667

26. Gulec MY, et al. Cloninger's Temperament and Character Dimension of Personality in Patients with Asthma. Int J Psychiatry Med 2010;40(3):273-287. doi:10.2190/PM.40.3.d

27. Alexander, Franz; Flagg GW. The psychosomatic approach. In: Handbook of Clinical Psychology. B. B. Wolm 1965:855-957.

28. Braud LW, Lupin MN, Braud WG. The Use of Electromyographic Biofeedback in the Control of Hyperactivity. J Learn Disabil 1975;8(7):420-425. doi:10.1177/002221947500800704

29. Kandasamy A, Chaturvedi S, Desai G. Spirituality, distress, depression, anxiety, and quality of life in patients with advanced cancer. Indian J Cancer 2011;48(1):55. doi:10.4103/0019-509X.75828

30. Zackheim L. Alexithymia: the expanding realm of research. J Psychosom Res 2007;63:345-347 doi:10.1016/j.jpsychores.2007.08.011

31. Porcelli P, Taylor GJ. Alexithymia and physical illness: a psychosomatic approach. In: Luminet O, Bagby RM, Taylor GJ, eds. Alexithymia: Advances in Research, Theory, and Clinical Practice. New York: Cambridge University Press, 105-126 doi:10.1017/9781108241595.

32. Vazquez I, et al. The Role of Alexithymia in Quality of Life and Health Care Use in Asthma. J Asthma 2010;47(7):797-804. doi:10.3109/02770900903560217

33. Feldman JM, Lehrer PM, Hochron SM. The predictive value of the Toronto Alexithymia Scale among patients with asthma. J Psychosom Res Published online 2002. doi:10.1016/S0022-3999(02)00452-X

34. Amore $\mathrm{M}$, et al. Disease Control in Patients with Asthma is Associated with Alexithymia but not with Depression or Anxiety. Behav Med 2013;39:138-145. doi:10.1080/08964289.2013.818931 